\title{
The Search for the Meaning of Soil Health: Lessons from Human Health and Ecosystem Health
}

\author{
Ee Ling $\mathrm{Ng}{ }^{1, *}$ (D) and Junling Zhang ${ }^{2}$ \\ 1 School of Agriculture and Food, Faculty of Veterinary and Agricultural Sciences, \\ The University of Melbourne, Victoria 3010, Australia \\ 2 Centre for Resources, Environment and Food Security, College of Resources and Environmental Sciences, \\ Key Laboratory of Plant-Soil Interactions, Ministry of Education, China Agricultural University, \\ Beijing 100193, China \\ * Correspondence: eeling.ng@unimelb.edu.au; Tel.: +61-390-355-703
}

Received: 13 May 2019; Accepted: 2 July 2019; Published: 5 July 2019

\begin{abstract}
Soil is central to human wellbeing through its provision of critical ecosystem services, including food and clean water. These services emerge through the self-organising nature of the soil system. Here, we consider the lessons learnt from the evolution of the understanding of human and ecosystem health for the conceptualisation and application of soil health. We share the fundamental and practical challenges of managing the land with respect to soil health, and the need for policy to drive the protection of soil as one of our most important non-renewable natural resources.
\end{abstract}

Keywords: sustainability; agriculture systems; soil quality; soil fertility; sustainable development goal; smallholder farmers

\section{Introduction}

Soil is central to human wellbeing, because it provides food, fibre, fuel, clean water and regulation of greenhouse gases. The sustained provision of these services and resources are central to our ability to feed the growing world population with not only sufficient calories but also nutrition to support human wellbeing. We are also at a time of cultural revolution worldwide, with a diet change towards higher animal product consumption in the world's emerging middle classes. One-third of global agricultural land and $26 \%$ of the world's land area are dedicated to the production of feed and grazing, respectively, amounting to 4 billion ha of the planet's land area being dedicated to raising livestock [1]. This demand for animal products puts tremendous pressure on soil's ability to support human health, food security and environmental targets of the 2030 Sustainable Development Goals and beyond. Nevertheless, securing those services and benefits from soil will be the key to humans continuing to live on this land [2]. These benefits from soil are emergent properties of soil, arising not only from the sum of its components but also as a result of the interaction among these components. In our attempt to capture the source of these benefits, we use the terms soil quality, soil fertility and soil health loosely and interchangeably. Here, we deliberate over the meaning of soil health, as it is currently and vaguely used, and how the understanding of human and ecosystem health-concepts which have evolved over a longer period of time - can help us create a more meaningful interpretation of soil health. Furthermore, through examples, we illustrate the fundamental and practical challenges to sustainably managing soil health.

\section{Current Definitions of Soil Health}

Soil health is currently defined via the following iterations: (1) "the capacity of a living soil to function, within natural or managed ecosystem boundaries, to sustain plant and animal productivity, 
maintain or enhance water and air quality, and promote plant and animal health" [3], (2) "a healthy agricultural soil is one that is capable of supporting the production of food and fibre, to a level and with a quality sufficient to meet human requirements, together with continued delivery of other ecosystem services that are essential for maintenance of the quality of life for humans and the conservation of biodiversity" [4], and (3) "the continued capacity of soil to function as a vital living ecosystem that sustains plants, animals and humans" [5].

These definitions are anthropocentric in nature and adopt an ecosystem viewpoint of soil. While soil health, soil fertility and soil quality are used loosely and interchangeably in this paper, soil quality and soil fertility have longer histories of use and are particularly closely associated with agriculture. The definition of soil health has been relatively stable since the 2000s as indicated by the list of definitions collected by Mizuta et al. [6], and efforts are now focused more on operationalising it in terms of developing an integrative approach to capturing soil health in its entirety and complexity despite the questions remaining about the concept itself. Given the developments in ecosystem health and human health, we believe it is worth revisiting the concept using lessons learnt from these two research areas. To be clear, we are focused on how we think conceptually about soil health through the lens of human health and ecosystem health. The current debate over the merits of using the term soil quality over the term soil health has many similarities to the debates over the concept of the term soil quality in the 1990s, and we refer our readers to Sojka and Upchurch [7], Karlen et al. [8], Karlen et al. [9], Mizuta et al. [6] and Bünemann et al. [10] for in-depth explanations of the evolution of this terminology and the related concepts. We share the opinion expressed by Sojka and Upchurch [7] and Karlen et al. [8] that we must not let disagreement about terminology stand in the way of keeping our children and grandchildren fed, safe and healthy within the planetary boundary.

\section{What Can Human Health Teach Us about Soil Health?}

"If we take a man as he is, we make him worse; but if we take him as he should be, we help him become what he can be" -Wolfgang von Goethe

Soil is a living system, and therefore, the basic requirements for the health of soil systems are similar to that of humans - they need an exchange of gases with the atmosphere, food and water for growth and maintenance and shelter from biological and physical threats. Using human health as a metaphor for soil has converted soil from being viewed as a stage, where anthropogenic actions have cascading consequences, to an actor, that is, a dynamical living system that can be tamed. With soil health, it is possible to consider the degraded system as transiently sick and capable of recovering its health. This way of thinking works well particularly with our wish to improve soil, whether it is for the purpose of food production or otherwise.

Taking a cue from the concept of holistic health, health is not simply the absence of disease but encompasses wellbeing [11]. The World Health Organisation defines health as "a state of complete physical, mental and social wellbeing, not merely the absence of disease or infirmity" [12]. The concept of health as applies to humans gives rise to two key challenges to the concept of soil health: (1) what are the measures of wellbeing in the context of soil, and (2) what are the baseline values of soil health? We know the healthy baseline of heart rate or blood pressure of a healthy person, but what can we say about soil health baselines? The baselines for soil health cannot be transferred automatically across different ecosystems. Can we divide soil health into ages/stages, as we do to mark the health of a human at different stages in life? Or do we break it down into the roles we want it to serve and the state of health it needs to serve that purpose?

While it is difficult to quantify soil health, the cost of the loss of soil health is perhaps somewhat simpler, if not easier, to conceptualise. The loss of soil health may manifest itself as land degradation, which the United Nations Convention to Combat Desertification defines as the following:

The reduction or loss of biological and economic productivity in rainfed cropland, irrigated cropland or range, pasture, forest and woodlands resulting from land uses or from a process or 
combination of processes, ... such as: soil erosion caused by wind and/or water, deterioration of the physical, chemical and biological or economic properties of soil, and long-term loss of natural vegetation. [13]

Global production loss in wheat, rice, maize and barley grain yields due to soil depletion of nitrogen, phosphorus and potassium were estimated to be 210, 491 and 433 Tg equivalent rice grain yield per year, respectively, in 2000 [14]. Qadir et al. [15] estimated that the costs of salt-induced crop yield loss in irrigated cropland was $\$ 27$ billion in 2013. Overall, 1.5 billion people were estimated to live on degrading agricultural land in 2010 [16]. Land degradation is both a cause and a result of poverty [17]. Land degradation can also be a result of economic growth, through an economic system based on profit that neglects unrated and unpaid services, such as regulating services.

As these estimates indicate, we generally consider the meaning of soil health in the context of crop yield and food nutrition, even though we know soil is also an important sink of carbon, a source of pharmaceuticals, a water filter and one of the most biodiverse habitats. A healthy soil determined purely on its ability to supply goods is equivalent to measuring human health based on a person's ability to do work or a person's economic value as a member of the society. With respect to soil's wider role, how we measure it depends on the desired endpoint of soil management and the value of soil in the context of the local or regional sociocultural and environmental needs of the community. The human health metaphor is helpful in that it highlights the need to look more holistically at soil health. How we can translate physical fitness to overall wellbeing in soil is captured by some conceptual advances in ecosystem health theories.

\section{What Can Ecosystem Health Teach Us about Soil Health?}

A widely used definition of a healthy ecosystem is "one that is sustainable-that is, it has the ability to maintain its structure (organization) and function (vigor) over time in the face of external stress (resilience)" [18]. Based on this definition of a healthy ecosystem and considering that soil itself can be evaluated as an ecosystem, a healthy soil is able to maintain a certain level of structural (physical, chemical and biological) and functional integrity in a changing environment. This perspective of soil health presents us with a meaningful way to describe soil in its complex gestalt system form, bringing us closer to the wellbeing description of health.

The soil ecosystem in its complex gestalt system form is self-organising, that is, a system of feedback loops between the biological and physicochemical components [19]. It has been proposed that the self-organising nature of the soil system is controlled by a set of critically interconnected aggregate functions-carbon transformation, nutrient cycling, maintenance of soil structure and biological regulation of soil population [4]. The outcome of this self-organisation relies on the biological component evolving with the prevailing physicochemical conditions while leaning on and learning from its memory or historical legacy $[20,21]$. Using the four critical processes mentioned by Kibblewhite et al. [4], the rates of these processes relative to one another may be a way to measure the components of resilience, vigour and organisation for comparison of the relative health of similar ecosystems and to identify changes of interest to humans. One proxy measure of resilience proposed by Costanza and Mageau [18] is the ratio of gross primary production per unit respiration, whereby they hypothesised that a system that has more energy in reserve will recover more quickly and easily from disturbance. Recent global analysis by Bond-Lamberty and colleagues [22] examined the ratios of both heterotrophic and total soil respiration to gross primary production and found that both ratios have increased from 1990 to 2014. Following the hypothesis of Costanza and Mageau, this would suggest that soil in evergreen forests, deciduous forests, grassland and shrubland globally—managed or natural—is showing a trend of lower energy in reserve, and therefore, it is decreasing in resilience

This concept of ecosystem health, which is quite similar to some iterations of the soil health definition currently used, indicates an operational problem. More specifically, Constanza and Mageau's definition [18] considers balance between organisation and resilience utmost and gives more flexibility to "a range of system vigor". An ecosystem with very high vigour is often in an early stage of 
ecosystem succession, and a climax ecosystem, such as a tropical rainforest, may have low resilience to large-scale disturbance [23]. As such, the balance amongst vigour, resilience and organisation means that compromise is necessary if we want to maximise one component of the system. This leads to practical challenges when we think of soil health, particularly where it is mostly used currently, that is, in agriculture.

\section{The Practical Challenges of Operationalising Soil Health}

When translated to how we manage soils for agriculture, soil management activities can be classified as actions to meet a human demand for a specific ecosystem service, which can be broadly classified into provisional, cultural and regulation services [24]. The respective actions are taken to retrieve, harvest or benefit more of one ecosystem service than would be provided naturally on the specific management level via the self-organising capacity naturally achievable on that scale. Consequently, soil management fosters specific soil functions by manipulating natural species competition, tilling, planting target species, applying pesticides and adding fertilisers or water, which would not be available on the target scale otherwise, or removing water (by artificial drainage) to improve/achieve suitable site conditions for target plants or target communities.

Agriculture achieves vigour by trading off organisation and resilience. Overall, soil management activities on a field scale change the evolutionary trajectory of ecosystem development in such a way that provisional services are preferentially provided by ecosystems kept in a juvenile state, cultural services are provided by ecosystems in an intermediate state and the provision of regulation services is most efficiently provided by ecosystems close to their potential climax state. Hence, soil management targeting higher yields unavoidably reduces the capacity of the respective ecosystem to provide cultural and regulation services. In the following, we use China to illustrate this practical conundrum.

In China, the grand challenge of feeding 1.3 billion people is the big driving force for grain production. However, the doubling of production from 300 million tonnes in 1978 to 621 million tonnes in 2015 was accompanied by a fivefold increase in chemical fertilizer inputs (a threefold and 11-fold increase in $\mathrm{N}$ and $\mathrm{P}$ fertilizers, respectively), which led to low efficiency of resource use and widespread soil degradation and environmental pollution $[25,26]$. Soil is treated as a cultivating substrate without considering its inherent properties, such as its maximal potential for yield and carbon sequestration. Consequently, high fertilizer inputs undermine plants' biological potential to mine soil nutrients and combat plant pathogens, leading to a vicious cycle of more chemical inputs to support plant health. In this regard, the internal metabolism and immunity of the soil, which are similar to gut microbiome in the regulation of human health, need to be considered. From the perspective of ecosystem health, such a leaky system has low resilience and can easily collapse into degraded land, and the soil may have to be abandoned or restored at high costs.

The concept of soil health has been communicated to local Chinese farmers for several years. Despite this, the current environmental problems indicate that farmers remain focused only on crop yield. From experience in developed countries, we have observed that top-down policy drives the protection of soil before public awareness catches up and reaches the tipping point, where the farmers themselves become soil health advocates. At the start, farmers do not necessarily see nor understand the benefit of the protection of soil, but if given appropriate incentives, we can essentially buy time for the benefits to eventualise and become clear to farmers. To this end, a series of measures were taken by the Ministry of Agriculture of China. Some of the successful practical measures included conservation tillage, national soil testing and fertilizer recommendation (STFR), straw return and implementing a zero-growth plan in chemical fertilizer use $[27,28]$. These policies that have achieved some degree of success in promoting soil health share common features-they are national policies with central investment and legal instruments that are matched with local governments' investment, enforcement and locally relevant concrete actions to implement the policies and willing farmers. The latter remains the most difficult factor to change in a country of 200-300 million smallholder farmers of diverse socioeconomic backgrounds. Subsidies in variable forms are critical, particularly in cash and fertilizers, 
as these smallholder farmers usually have low risk tolerance for change. These farmers also need to perceive clear gains, such as in the case of clear sky when straw was returned instead of burnt. Finally, these changes need to be perceived as socially acceptable, such as in the case of cover cropping in vineyards, where farmers were unwilling to implement change for fear of being perceived as lazy farmers by their community if the grounds were not kept clear of undergrowth.

As such, the successes of the past decade support the need to implement top-down policies to ensure soil health in China, as has occurred elsewhere in developed countries. The right policies will allow for the transformation of production-only driven agriculture into holistic green development and lifestyles for sustainable intensification and rural revitalisation. The ultimate goals are not only environmental protection and food security but also allowing rural society to achieve a better quality of community life and a sense of wellbeing, summarily known in China as green input, green cultivation, green products, friendly environment and happy people.

\section{Concluding Thoughts}

The use of the term soil health has evolved from the capacity of an anthropogenic system for intention and foresight, technology and communication and the recognition of the self-organising nature of soil ecosystems. As a system with multiple stakeholders, this form of meaningful analogy has and will continue to aid in communication and problem-solving as people identify strongly with the concept of health. The philosophy of soil health still requires discussion, despite over two decades of use. The choice of a definition reflects aspects of health that we value, but what we value and expect are not necessarily realistic. This is demonstrated by the challenge of operationalising soil health even within the narrow context of cropland. As a means to an end, soil health has served an important purpose to enable soil scientists to reach out to policymakers and the public. But the ends ultimately require top-down policy-driven changes to manage soil health for the common good, or we risk the tragedy of the commons.

Author Contributions: Conceptualization, E.L.N.; Investigation, E.L.N. and J.Z.; Data Curation, E.L.N. and J.Z.; Resources, E.L.N. and J.Z.; Original Draft Preparation, E.L.N. and J.Z.; Writing-Review and Editing, E.L.N. and J.Z.; Visualization, E.L.N.

Funding: This work was supported by funding from the National Key Research and Development Program of China (2016YFE0101100), the National Basic Research Program of China (2015CB150501) and the Australia-China Joint Research Centre-Healthy Soils for Sustainable Food Production and Environmental Quality (ACSRF48165).

Acknowledgments: Our ideas were formulated over a decade and in dialogue with many valued peers. We dedicate this to the late Wilhelm Windhorst, with whom NEL had many discussions about the translation of ecosystem health theories to soil health practice. His wisdom and generosity with his students were an inspiration to those who had the privilege to receive his guidance.

Conflicts of Interest: The authors declare no conflicts of interest.

\section{References}

1. Food and Agriculture Organization of the United Nations. World livestock: Transforming the livestock sector through the Sustainable Development Goals; Rome, Italy, 2018. Available online: http://www.fao.org/3/ CA1201EN/ca1201en.pdf (accessed on 15 April 2019).

2. Janzen, H.; Fixen, P.E.; Franzluebbers, A.J.; Hattey, J.; Izaurralde, R.C.; Ketterings, Q.M.; Lobb, D.A.; Schlesinger, W.H. Global Prospects Rooted in Soil Science. Soil Sci. Soc. Am. J. 2011, 75, 1-8. [CrossRef]

3. Doran, J.W. Soil health and global sustainability: Translating science into practice. Agric. Ecosyst. Environ. 2002, 88, 119-127. [CrossRef]

4. Kibblewhite, M.G.; Ritz, K.; Swift, M.J. Soil health in agricultural systems. Philos. Trans. R. Soc. B Biol. Sci. 2008, 363, 685-701. [CrossRef]

5. USDA. Natural Resources Conservation Service. Healthy Soil for Life. 2018. Available online: https: //www.nrcs.usda.gov/wps/portal/nrcs/main/soils/health/ (accessed on 31 July 2018).

6. Mizuta, K.; Grunwald, K.; Phillips, M.A. New soil index development and integration with econometric theory. Soil Sci. Soc. Am. J. 2018, 82, 1017-1032. [CrossRef] 
7. Sojka, R.E.; Upchurch, D.R. Reservations regarding the soil quality concept. Soil Sci. Soc. Am. J. 1999, 63, 1039-1054. [CrossRef]

8. Karlen, D.L.; Andrews, S.S.; Weinhold, B.J.; Doran, J.W. Soil quality: Humankind's foundation for survival. J. Soil Water Conserv. 2003, 58, 171-179.

9. Karlen, D.L.; Andrews, S.S.; Zobeck, T.M.; Wienhold, B.J. Soil Quality Assessment: Past, Present and Future. Publication from USDA-ARS/UNL Faculty. Available online: http://digitalcommons.unl.edu/usdaarsfacpub/ 1203 (accessed on 12 June 2019).

10. Bünemann, E.K.; Bongiorno, G.; Bai, Z.; Creamer, R.E.; Deyn, G.D.; Goede, R.d.; Fleskens, L.; Geissen, V.; Kuyper, T.W.; Mader, P.; et al. Soil quality-A critical review. Soil Biol. Biochem. 2018, 120, 105-125. [CrossRef]

11. Waltner-Toews, D. Concepts and Principles In Agroecosystems Health. In Agro-ecosystem health, Proceedings of WIAS seminar, Wageningen, The Netherlands, 26 September 1996; Bruchem, J.v., Ed.; NRLO-rapport No 97/31; 1997; pp. 9-22.

12. World Health Organisation. Constitution of the World Health Organization. 2018. Available online: https://www.who.int/governance/eb/who_constitution_en.pdf (accessed on 31 July 2018).

13. UNCCD (United Nations Convention to Combat Desertification). United Nations Convention to Combat Desertification Statute. 1994. Available online: catalogue.unccd.int/936_UNCCD_Convention_ENG.pdf (accessed on 12 June 2019).

14. Tan, Z.X.; Lal, R.; Wiebe, K.D. Global Soil Nutrient Depletion and Yield Reduction. J. Sustain. Agr. 2005, 26, 123-146. [CrossRef]

15. Qadir, M.; Quillérou, E.; Nangia; Murtaza, V.G.; Singh, M.; Thomas, R.J.; Drechsel, P.; Noble, A.D. Economics of salt-induced land degradation and restoration. Nat. Resour. Forum 2014, 38, 282-295. [CrossRef]

16. Barbier, E.B.; Hochard, J.P. Does Land Degradation Increase Poverty in Developing Countries? PLoS ONE 2016, 11. [CrossRef] [PubMed]

17. UNCCD (United Nations Convention to Combat Desertification). Global Land Outlook; Secretariat of the United Nations Convention to Combat Desertification: Bonn, Germany, 2017; 336p.

18. Costanza, R.; Mageau, M. What is a healthy ecosystem? Aquat. Ecol. 1999, 33, 105-115. [CrossRef]

19. Young, I.M.; Crawford, J.W. Interactions and Self-Organization in the Soil-Microbe Complex. Science 2004, 304, 1634-1637. [CrossRef] [PubMed]

20. Strickland, M.S.; Lauber, C.; Fierer, N.; Bradford, M.A. Testing the functional significance of microbial community composition. Ecology 2009, 90, 441-451. [CrossRef] [PubMed]

21. Keiser, A.D.; Strickland, M.S.; Fierer, N.; Bradford, M.A. The effect of resource history on the functioning of soil microbial communities is maintained across time. Biogeosciences 2011, 8, 1477-1486. [CrossRef]

22. Bond-Lamberty, B.; Bailey, V.L.; Chen, M.; Gough, C.M.; Vargas, R. Globally rising soil heterotrophic respiration over recent decades. Nature 2018, 560, 80-83. [CrossRef] [PubMed]

23. Holling, C.S. The resilience of terrestrial ecosystems: local surprise and global change. In Sustainable Development of the Biosphere; Clark, W.C., Munn, R.E., Eds.; Cambridge University Press: Cambridge, UK, 1986; pp. 292-317.

24. Millennium Ecosystem Assessment. Ecosystems and Human Well-Being: Synthesis; Island Press: Washington DC, USA, 2005; 139p.

25. Vitousek, P.M.; Naylor, R.; Crews, T.; David, M.B.; Drinkwater, L.E.; Holland, E.; Johnes, P.J.; Katzenberger, J.; Martinelli, L.A.; Matson, P.A.; et al. Nutrient Imbalances in Agricultural Development. Science 2009, 324, 1519-1520. [CrossRef] [PubMed]

26. West, P.C.; Gerber, J.S.; Engstrom, P.M.; Mueller, N.D.; Brauman, K.A.; Carlson, K.M.; Cassidy, E.S.; Johnston, M.; et al. Leverage points for improving global food security and the environment. Science 2014, 345, 325-328. [CrossRef] [PubMed]

27. Veeck, G.; Shui, W. China's Quiet Agricultural Revolution: Policy and Programs of the New Millennium. Eurasian Geogr. Econ. 2011, 52, 242-263. [CrossRef]

28. Cui, Z.; Zhang, H.; Chen, X.; Zhang, C.; Ma, W.; Huang, C.; Zhang, W.; Mi, G.; Miao, Y.; Li, X.; et al. Pursuing sustainable productivity with millions of smallholder farmers. Nature 2018, 555, 363-366. [CrossRef] [PubMed]

(C) 2019 by the authors. Licensee MDPI, Basel, Switzerland. This article is an open access article distributed under the terms and conditions of the Creative Commons Attribution (CC BY) license (http://creativecommons.org/licenses/by/4.0/). 